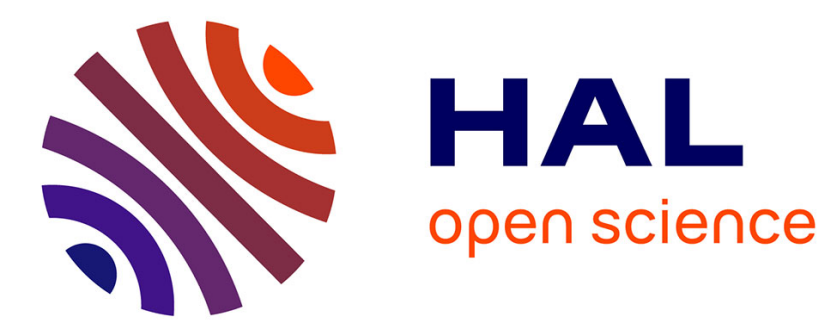

\title{
Reference values for vastus lateralis fiber type proportion and fiber size
}

Fares Gouzi, Jonathan Maury, Nicolas Molinari, Pascal Pomiès, Jacques

Mercier, Christian Prefaut, Maurice Hayot

\section{To cite this version:}

Fares Gouzi, Jonathan Maury, Nicolas Molinari, Pascal Pomiès, Jacques Mercier, et al.. Reference values for vastus lateralis fiber type proportion and fiber size. Journal of Applied Physiology, 2014, 10.1152/japplphysiol.01332.2013 . hal-02565532

\section{HAL Id: hal-02565532 \\ https://hal.umontpellier.fr/hal-02565532}

Submitted on 6 May 2020

HAL is a multi-disciplinary open access archive for the deposit and dissemination of scientific research documents, whether they are published or not. The documents may come from teaching and research institutions in France or abroad, or from public or private research centers.
L'archive ouverte pluridisciplinaire HAL, est destinée au dépôt et à la diffusion de documents scientifiques de niveau recherche, publiés ou non, émanant des établissements d'enseignement et de recherche français ou étrangers, des laboratoires publics ou privés. 


\title{
Reference values for vastus lateralis fiber type proportion and fiber size
}

\author{
Fares Gouzi, ${ }^{1,2}$ Jonathan Maury, ${ }^{1,2}$ Nicolas Molinari, ${ }^{3}$ Pascal Pomiès, ${ }^{1}$ Jacques Mercier, ${ }^{1}$ \\ Christian Préfaut, ${ }^{1}$ and Maurice Hayot ${ }^{1}$ \\ ${ }^{1}$ INSERM U-1046, CHRU Montpellier, Department of Clinical Physiology, University of Montpellier I and II, Montpellier, \\ France; ${ }^{2}$ Pulmonary Rehabilitation Center "La Solane", Fontalvie Group, Osséja, France; and ${ }^{3}$ UMR 729 MISTEA, CHRU \\ Montpellier, Department of Medical Information, University of Montpellier I, Montpellier, France
}

TO THE EDITOR: In a previous issue of the Journal of Applied Physiology, Gosker and Schols (1) commented on the reference values for fiber CSA of the vastus lateralis of the quadriceps in healthy subjects $>40$ years old.

First, we are pleased to read that the fiber CSA values provided by our meta-analysis are significantly correlated with the Maastricht team's data from healthy subjects. This reinforces our findings, because data from a healthy population were not included in our systematic review. Moreover, the data on type I fiber proportions published by Gosker et al. agree with data obtained using a systematic approach (2). Altogether, the data provided by Gosker and Schols validate our publication.

However, the authors contest the statement that the reference values for type I fiber proportion in our study are more valid than those published previously by their group (1). This statement in no way diminishes the merit of the paper from Gosker et al. because they systematically reviewed only studies of COPD patients and provided results similar to those found in our study. Yet the systematic review process was not performed in the same way for healthy subjects, as stated in their methods section: "For control values of quadriceps femoris fibre type proportions we used age-matched healthy control groups of the COPD related papers described above" (2). Therefore, nine studies matching the inclusion criteria for the systematic review in healthy subjects included in our metaanalysis were missed.

Conversely, we do not contest the limited usefulness of our reference values for fiber CSA in the context of a drastic fiber type switch. In under $33 \%$ of type I fiber, the lower limits of the normal (LLNs) are $1,255 \mu \mathrm{m}^{2}$ and $826 \mu \mathrm{m}^{2}$, respectively, in men and women, which is low. In our cohort of 39 COPD patients, we found that, using our published LLNs, 2/39 (5\%) COPD patients had fiber atrophy. This is discrepant with the $20 \%$ recently reported (4) using a different methodology. However, given the variability inherent to sampling from a small group $(n=30)$, the LLNs in this latter study should have been considered as random variables with their own mean and

Address for reprint requests and other correspondence: F. Gouzi, INSERM U-1046, Univ. Montpellier I, Univ. Montpellier II, Dept. of Clinical Physiology, CHRU Montpellier, 34295 Montpellier cedex 5, France (e-mail: f-gouzi @ chu-montpellier.fr).
SD. Thus the real LLNs should have taken this variability into account and must, in fact, have been much lower.

As explained in our discussion section, the low LLNs obtained in our meta-analysis are the consequence of the remaining variability of the fiber CSA. Yet, the fiber CSA coefficients of variation $(\mathrm{CVs})$ are lower than the $\mathrm{CVs}$ in studies with small sample sizes $(3,4)$ and in agreement with the CV obtained in a study (5) with a similarly large sample $(n=418)$. The variability of fiber CSA can be explained by several factors and may indicate its potential sensitivity to external factors, which is mandatory for a potential biomarker.

Altogether, our conclusion that "ongoing work with inclusions of new studies of well-characterized populations of healthy subjects will further optimize these reference values by reducing the present variability in fiber CSA and proportions" is consistent with the limitation reported in the letter from Gosker and Schols. Therefore, we invite the Maastricht team to join us in the multicentric study that we are now designing to improve the accuracy of the current reference values in healthy subjects.

\section{DISCLOSURES}

No conflicts of interest, financial or otherwise, are declared by the author(s).

\section{AUTHOR CONTRIBUTIONS}

Author contributions: F.G., J. Maury, and N.M. drafted manuscript; F.G., C.-G.P., and M.H. edited and revised manuscript; F.G., J. Maury, N.M., P.P., J. Mercier, C.-G.P., and M.H. approved final version of manuscript.

\section{REFERENCES}

1. Gosker HR, Schols AM. Reference values for vastus lateralis fiber type proportions and fiber size. J Appl Physiol 115: 771, 2013.

2. Gosker HR, Zeegers MP, Wouters EF, Schols AM. Muscle fibre type shifting in the vastus lateralis of patients with COPD is associated with disease severity: a systematic review and meta-analysis. Thorax 62: $944-$ 949, 2007.

3. Gouzi F, Prefaut C, Abdellaoui A, Roudier E, de Rigal P, Molinari N, Laoudj-Chenivesse D, Mercier J, Birot O, Hayot M. Blunted muscle angiogenic training-response in COPD patients versus sedentary controls. Eur Respir J 41: 806-814, 2013.

4. Natanek SA, Gosker HR, Slot IG, Marsh GS, Hopkinson NS, Man WD, Tal-Singer R, Moxham J, Kemp PR, Schols NM, Polkey MI. Heterogeneity of quadriceps muscle phenotype in chronic obstructive pulmonary disease (COPD); implications for stratified medicine? Muscle Nerve 48: 488-497, 2013.

5. Simoneau JA, Bouchard C. Human variation in skeletal muscle fiber-type proportion and enzyme activities. Am J Physiol Endocrinol Metab 257: E567-E572, 1989. 